\title{
Vitamin D Receptor Polymorphism and Cancer: An Update
}

\author{
VIKRANT RAI, JOE ABDO, SWATI AGRAWAL and DEVENDRA K. AGRAWAL
}

Department of Clinical and Translational Science, Creighton University School of Medicine, Omaha, NE, U.S.A.

\begin{abstract}
Background: Vitamin D mediates its action via vitamin $D$ receptor $(V D R)$ and is involved in a wide variety of biological processes including regulation of cell proliferation and differentiation in normal tissue and apoptosis, and cell adhesion in tumor cells. The study of genetic variations in VDR may elucidate the association of vitamin D levels, its metabolism, and VDR polymorphism with various diseases and cancer. The association of VDR polymorphism with cancer has been reported; however, the literature lacks critical analyses of the studies in last 3 years. Materials and Methods: A systematic search of PubMed database (2015 through mid-2017) was conducted to provide a comprehensive overview of this clinical arena. Results: Studies on the association of VDR polymorphisms FokI, BsmI, TaqI, and ApaI and cancer have suggested the involvement of VDR polymorphism in tumorigenesis. Conclusion: The inconsistent results and lack of the studies in some cancer types warrant additional research.
\end{abstract}

Vitamin D is involved in a wide variety of biological processes including bone metabolism, modulation of the immune response, and regulation of cell proliferation and differentiation. Vitamin D has a substantial function in overall human health, including cancer occurrence (1). Vitamin D regulates cellular differentiation and proliferation in normal tissue and regulates proliferation, apoptosis, and cell adhesion at the tumor cell level. It also modifies tumor angiogenesis, invasion, and metastasis

This article is freely accessible online.

Correspondence to: Devendra K. Agrawal, Ph.D. (Biochem), Ph.D. (Med Sci), MBA, Professor \& Chairman, Department of Clinical \& Translational Science, The Peekie Nash Carpenter Endowed Chair in Medicine, CRISS II Room 510, Creighton University School of Medicine, 2500 California Plaza, Omaha, NE 68178, U.S.A. Tel: +1 4022802938, Fax: +1 4022801421, e-mail: Dkagr@creighton.edu

Key Words: Vitamin D, VDR polymorphism, breast cancer, prostate cancer, gastrointestinal tract cancer, urological cancer, hematological cancer, pediatric cancer, review. along with decreasing oxidative DNA damage (2). Vitamin D mediates its biological action via the vitamin D receptor (VDR) (3). VDR is a steroid intracellular hormone receptor which binds to $1,25(\mathrm{OH}) 2 \mathrm{D}$ and interacts with vitamin $\mathrm{D}$ receptor response elements (VDRE) of the target genes to produce various biological effects (4). The VDR gene lies on the long arm of chromosome 12 (12q12-14) and has approximately 200 single nucleotide polymorphisms (SNPs) (5). The most common allelic variants studied includes a start codon polymorphism FokI (T/C) in exon II, BsmI (A/G) and ApaI (C/A) polymorphisms in the intron between exon VII and IX and a TaqI (T/C) variant in exon IX (6). The most commonly studied VDR polymorphisms include Fok1 (rs2228570), Apa1 (rs7975232), Bsm1 (rs1544410), Bgl1 (rs739837), and restriction fragment length polymorphisms rs7975232 (G/T substitution), rs1544410 (A/G substitution), and rs739837 (G/T substitution) (7). Since vitamin $\mathrm{D}$ acts through VDR, studying genetic variations in VDR may elucidate the association of altered vitamin D levels and metabolism, VDR polymorphism, and cancer. This systemic review focused on pooling the case-control studies and metaanalyses performed in the past 3 years (2015-mid 2017) for the association of $V D R$ polymorphism and cancer.

\section{Materials and Methods}

A systematic search of the PubMed database (January 2015 through mid-2017) of the National Library of Medicine was performed using the following Medical Subject Headings: cancer, vitamin D, VDR polymorphism, tumor, breast cancer, female reproductive tract cancer, prostate cancer, skin cancer, gastrointestinal tract, esophageal cancer, colorectal cancer, urinary tract cancer, pediatric tumors, hematologic cancer. We included articles that examined and described the $V D R$ polymorphisms in relation to risk and incidence of cancer. Articles that were not written in English, conference abstracts and studies not performed on humans were excluded.

\section{VDR Polymorphism and Cancer}

$V D R$ SNPs within the gene coding for VDR may influence cancer risk (8). Numerous investigations have analyzed $V D R$ affiliated SNPs; however, their general association with 


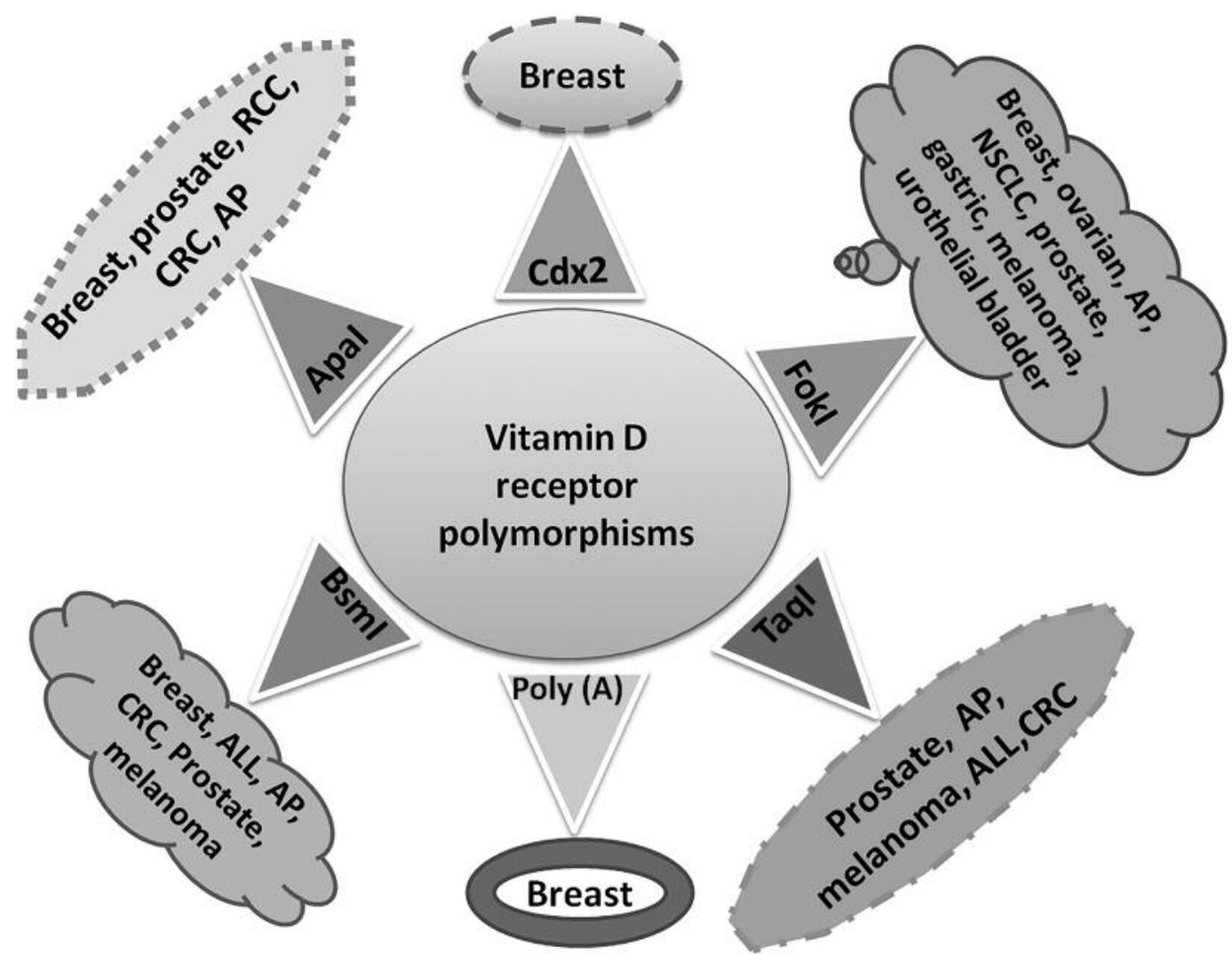

Figure 1. Vitamin D receptor (VDR) polymorphisms associated with increased risk of cancer. The presence of these polymorphisms is associated with an increased risk of cancer. However, these relationships may vary with age, ethnicity, and race as discussed in the text. ALL: Acute lymphoblastic leukaemia, AP: adenomatous polyposis, CRC: colorectal cancer, NSCLC: non-small cell lung cancer, RCC: renal cell carcinoma.

carcinogenesis remains controversial. Significant associations between $V D R$ polymorphisms and breast (Fok1, Bsm1, Apa 1$)$, prostate (Fok1, Bsm1, Taq1), colorectal (Fok1, Bsm1, Taq1) and skin cancer (Fok1, Bsm1, Taq1) have been reported (9). For instance, the CDX2 polymorphism (SNP - rs11568820) of the $V D R$ gene has been associated with cancer susceptibility amid varied results. Various researchers have conducted the meta-analysis to establish the viable association between $V D R$ polymorphism and cancer risk (10-22). A meta-analysis including 25 separate studies totaling 34,018 individuals published prior to March 2015 for $C D X 2$ polymorphism association with cancer conducted by Dai et al. demonstrated that in the homozygous model, CDX2 mutations were significantly associated with an increased cancer risk of colorectal and ovarian cancer, particularly in AfricanAmerican but not in Caucasians or Asians (10). Data-analysis of dominant, homozygous and recessive comparison models yielded a significant association between cancer risk and $C D X 2$ mutations in African-Americans. Stratifying the data by cancer types showed a strong association between $V D R$ $C D X 2$ polymorphisms and an amplified risk of colorectal and ovarian cancer (10). Gandini et al. analysed the association between VDR polymorphisms (Fok1,Bsm1, Taq1, Apa1, and $C d x 2$ ) and various types of cancer such as ovarian cancer, renal cell carcinoma, thyroid carcinoma, hepatocellular carcinoma (HCC), sarcoma, skin (melanoma and nonmelanoma skin cancer), bladder cancer, non-Hodgkin's lymphoma, leukaemia, oesophageal adenocarcinoma (EAC), head and neck and oral squamous cell carcinoma including 79 independent studies, for a total of 52427 cases and 62225 controls (9). The study concluded that significant associations exist between VDR polymorphisms and prostate (Fok1, Bsm 1, Taq1), breast (Fok1, Bsm1, Apa1), colorectal (Fok1, Bsm1, Taq1) and skin cancer (Fok1, Bsm1, Taq1) (Figures 1 and 2).

A meta-analysis between $V D R$ polymorphism including Cdx2 (rs11568820), FokI (rs2228570), BsmI (rs1544410), ApaI (rs7975232), and TaqI (rs731236) and the risks for female reproductive cancer such as breast, ovarian, cervical, endometrial, uterine and vaginal cancer, found an increased risk of developing breast and ovarian cancers with FokI polymorphism and reduced risk with BsmI polymorphism (19). A meta-analysis for the association between $V D R$ 


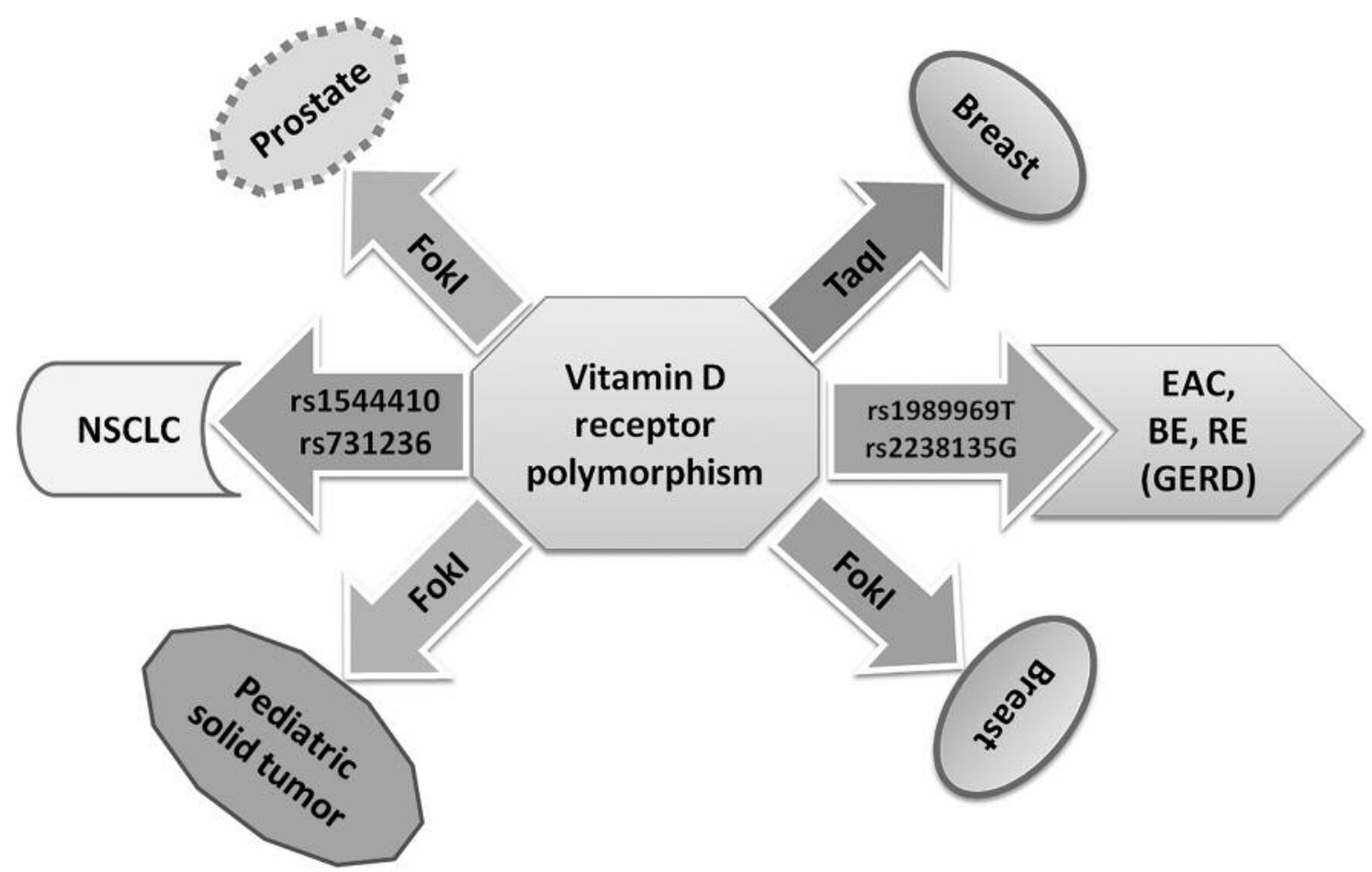

Figure 2. Vitamin D receptor (VDR) polymorphisms associated with reduced risk of cancer. The presence of these polymorphisms is associated with a reduced risk of cancer. However, these relationships may vary with age, ethnicity, and race as discussed in the text. BE: Barrett's oesophagus, EAC: oesophageal adenocarcinoma; GERD: gastro-oesophageal reflux disease, RE: reflux oesophagitis; NSCLC: non-small cell lung cancer.

polymorphism (TaqI, $A p a \mathrm{I}$, and $C d x 2)$ and the risk of basal cell carcinoma, colorectal cancer, EAC, hepatocellular carcinoma, head and neck cancer, non-Hodgkin lymphoma, oral squamous cell carcinoma, renal cell carcinoma, squamous cell carcinoma, and thyroid carcinoma found $C d x 2$ gg versus GG to be associated with a significantly increased risk for all cancer types and TaqI was associated with significantly increased risk for colorectal cancer (21) (Figures 1 and 2). Significant variations in frequency were also existent between diverse ethnic groups. VDR genotypes may have more significance when grouped with specific haplotypes, or when linked to additional gene polymorphisms involved in the vitamin D pathway, or when stratified by different tumor type or patient background (21). Nevertheless, there are clear intersections between the ability of VDR to function properly and carcinogenesis in a number of indications. This section focuses on the effect of $V D R$ polymorphisms in the entire gastrointestinal tract - where vitamin D-related patient management strategies hold much promise.

\section{Female Reproductive Tract Cancer}

$V D R$ polymorphism has been associated with cancer of the female reproductive including breast, ovarian, cervical, endometrial, uterine, and vaginal cancer (19). Increased expression of $V D R$ has been found in breast cancer and inversely related to aggressive tumor characteristics, including large tumor size, hormonal receptor (HR) negativity, triplenegative subtype [estrogen-receptor (ER) negative, progesterone receptor (PR) negative, and human epidermal growth factor receptor 2 (HER2) negative], and expression of proliferative marker Ki-67 (23). Similarly, various casecontrol studies suggested that the association between VDR polymorphism and risk of breast cancer may depend on race and ethnicity. Furthermore, these studies also showed inconsistent results, some suggesting the association of VDR polymorphism with breast cancer, while others suggested a lack of association $(3,19,24-31)$. No association between $V D R$ polymorphisms and breast cancer risk was found, however, modification of this relationship was observed with the menopausal status in Europeans (VDR rs4328262 and rs11168292) and East Asians (VDR rs11168287). Furthermore, heterogeneity by tumor subtype was also seen for rs 1544410 , rs7967152 and rs2239186 VDR polymorphisms in Europeans (30). These case-control and meta-analysis studies suggest that VDR polymorphism may be associated with increased risk of breast cancer (Table I). However, Shaikh et al. reviewed the impact of VDR gene polymorphisms Fok1, Bsm 1, Taq1, Apa1 
Table I. Vitamin D receptor (VDR) polymorphisms and female genital tract cancer.

\begin{tabular}{|c|c|c|c|c|}
\hline Type of study & Cancer type & $\begin{array}{l}\text { Number of study } \\
\text { subjects }\end{array}$ & $\begin{array}{l}\text { Polymorphism } \\
\text { under study }\end{array}$ & $\begin{array}{l}\text { Outcome of } \\
\text { the study }\end{array}$ \\
\hline Case-control study (3) & Breast & $\begin{array}{c}60 \text { Egyptian female patients with } \\
\text { breast cancer and } 60 \text { age matched } \\
\text { healthy control females }\end{array}$ & $B s m \mathrm{I}(\mathrm{A} / \mathrm{G})$ & $\begin{array}{l}\text { B Allele or Bb genotype of } V D R \text { may } \\
\text { be a susceptibility risk factor for } \\
\text { breast cancer development. }\end{array}$ \\
\hline Meta-analysis (16) & Breast & $\begin{array}{l}\text { Two case-control studies ( } 1,526 \text { cases } \\
\text { and } 2,058 \text { control in premenopausal } \\
\text { group) and five studies ( } 7,738 \text { cases and } \\
10,453 \text { control in postmenopausal group) }\end{array}$ & FokI & $\begin{array}{l}\text { FokI polymorphism is a risk factor } \\
\text { for breast cancer in post-menopausal } \\
\text { women but not in premenopausal women. }\end{array}$ \\
\hline Meta-analysis (17) & Breast & $\begin{array}{l}\text { Four prospective case-control studies } \\
\text { (case/control: } 270 / 554 ; 6473 / 8397 \\
6355 / 8149 ; 500 / 500)\end{array}$ & $\begin{array}{l}\text { Fok } 1, \\
\text { Bsm } 1, \text { Taq } 1, \\
\text { and Apa } 1\end{array}$ & $\begin{array}{l}\text { No significant association between } \\
\text { Fok } 1, B s m 1, \text { Taq } 1, \text { Apa } 1 \text { polymorphism, } \\
\text { and breast cancer risk in the general } \\
\text { as well as Caucasian population. }\end{array}$ \\
\hline Meta-analysis (19) & Breast & $\begin{array}{c}\text { Six ovarian cancer studies (13 individual } \\
\text { studies involving } 4107 \text { cases and } \\
6661 \text { controls) and } 29 \text { breast cancer } \\
\text { studies ( } 38 \text { individual studies involving } \\
16,453 \text { cases and } 22,044 \text { controls) }\end{array}$ & $\begin{array}{l}\text { Cdx2, FokI, } \\
\text { BsmI, ApaI, } \\
\quad \text { TaqI }\end{array}$ & $\begin{array}{c}\text { FokI and } B s m \mathrm{I} V D R \text { gene polymorphisms } \\
\text { may be significantly associated } \\
\text { with gynecological cancer. }\end{array}$ \\
\hline In vitro study (20) & Breast & $\begin{array}{c}\text { ER-positive (MCF7 and T-47D) } \\
\text { and ER-negative (MDA-MB-231, } \\
\text { SUM 159PT, SK-BR-3, BT549, } \\
\text { MDA-MB-468, HCC1143, BT20 and } \\
\text { HCC1954), human breast cancer cell lines }\end{array}$ & $\mathrm{Cdx} 2$ & $\begin{array}{l}C d x 2 \text { polymorphism is associated with } \\
\text { breast cancer and may be a potential } \\
\text { biomarker for vitamin } \mathrm{D} \text { treatment } \\
\text { in breast cancer. }\end{array}$ \\
\hline Case-control study (24) & Breast & $\begin{array}{l}130 \text { Post-menopausal breast cancer } \\
\text { cases aged } 49 \text { to } 65 \text { years and } 100 \\
\text { controls aged } 50 \text { to } 72 \text { years }\end{array}$ & $\begin{array}{c}\text { BsmI-rs1544410, } \\
\text { ApaI-rs7975232, } \\
\text { TaqI-rs731236 } \\
\text { FokI-rs } 10735810\end{array}$ & $\begin{array}{l}\text { Significantly increased risk of breast } \\
\text { cancer among carriers of BsmI bb } \\
\text { genotype and ApaI aa genotype. }\end{array}$ \\
\hline Case-control study (25) & Breast & $\begin{array}{l}261 \text { Blood samples, } 134 \text { women } \\
\text { with breast cancer and } 127 \text { controls }\end{array}$ & $\operatorname{poly}(\mathrm{A})$ & $\begin{array}{l}\text { Poly (A) variant } \mathrm{L} \text { allele is associated } \\
\text { with risk of breast cancer in } \\
\text { females of northern Iran. }\end{array}$ \\
\hline Case-control study (26) & Breast & $\begin{array}{l}60 \text { Females with breast cancer and } \\
30 \text { healthy controls of matched age }\end{array}$ & Bsm 1 (rs1544410) & $\begin{array}{l}\text { No association with breast } \\
\text { cancer risk. }\end{array}$ \\
\hline Case control study (27) & Breast & $\begin{array}{c}264 \text { Subjects (103 cases and } \\
161 \text { controls })\end{array}$ & $C d x^{2}$ & $\begin{array}{l}\text { Non-significant association between } \\
C d x 2 \text { and breast cancer, however the } \\
\text { GG genotype increases the risk of } \\
\text { developing cancer in southern Pakistan. }\end{array}$ \\
\hline Case-control study (28) & Breast & $\begin{array}{l}463 \text { Genetically enriched female } \\
\text { breast cancer cases with known } \\
\text { BRCA1/2 status and } 1,012 \text { controls }\end{array}$ & $\begin{array}{l}\text { BsmI (rs1544410), } \\
\text { FokI (rs2228570) }\end{array}$ & $\begin{array}{l}B s m \mathrm{I} \text { polymorphism may be } \\
\text { associated with increased breast } \\
\text { cancer risk in Pakistani women } \\
\text { negative for } B R C A 1 / 2 \\
\text { germline mutations. }\end{array}$ \\
\hline $\begin{array}{l}\text { Population-based } \\
\text { case-control study (29) }\end{array}$ & Breast & $\begin{array}{l}967 \text { Incident breast cancer } \\
\text { cases and } 993 \text { controls }\end{array}$ & $\begin{array}{l}\text { TaqI, BsmI } \\
\quad \text { ApaI }\end{array}$ & $\begin{array}{c}T a q \mathrm{I}(\mathrm{rs} 731236) \text { was significantly } \\
\text { associated with } 26 \% \text { risk reduction }\end{array}$ \\
\hline Case-control study (30) & Breast & 1037 Cases and 1050 controls & $\begin{array}{l}\text { rs4328262, rs11168292, } \\
\text { rs11168287, rs1544410, } \\
\text { rs7967152, rs2239186 }\end{array}$ & $\begin{array}{c}\text { No association between } V D R \\
\text { polymorphism and breast cancer. } \\
\text { Relationship may change } \\
\text { with menopausal status. }\end{array}$ \\
\hline Case-control study (31) & Breast & $\begin{array}{l}\text { Blood samples from } 95 \text { cancer } \\
\text { and } 71 \text { healthy individuals }\end{array}$ & FokI and BsmI & $\begin{array}{l}\text { Protective effect of the FokI } \\
\text { polymorphism and no association of } \\
\text { Bsml in breast cancer in West } \\
\text { Azerbaijan Province, Iran. }\end{array}$ \\
\hline Case-control study (33) & Breast & $\begin{array}{l}50 \text { Healthy donors from indigenous } \\
\text { black Tanzanian and a Caucasian } \\
\text { Italian population and } 35 \text { Caucasian and } \\
18 \text { African patients with breast cancer }\end{array}$ & $\begin{array}{l}\mathrm{A} 1012 \mathrm{G}, C d x 2 \\
\text { and } F o k 1\end{array}$ & $\begin{array}{l}\text { Significantly higher frequency of } \\
\text { AA } C d x 2 \text { and CC Fok } 1 \text { in Africans. }\end{array}$ \\
\hline Case-control study (34) & Ovarian & 245 patients and 465 healthy controls & $\begin{array}{c}\text { FokI } \\
(\text { rs } 2228570)\end{array}$ & $\begin{array}{l}\text { FokI is a risk factor for ovarian cancer } \\
\text { in non-carriers of } B R C A 1 / B R C A 2 \\
\text { mutations in the Polish population. }\end{array}$ \\
\hline Case-control study (35) & Ovarian & 100 Controls and 100 patients & FokI, Taq 1 & $\begin{array}{l}\text { FokI might be a risk factor for } \\
\text { the development of ovarian cancer. }\end{array}$ \\
\hline
\end{tabular}

ER: Estrogen receptor; BRCA1/2: breast cancer susceptibility gene 1/2. 
Table II. Vitamin D receptor (VDR) polymorphisms and prostate cancer.

\begin{tabular}{|c|c|c|c|}
\hline Type of study & $\begin{array}{l}\text { Number of study } \\
\text { subjects }\end{array}$ & $\begin{array}{l}\text { Polymorphism } \\
\text { under study }\end{array}$ & $\begin{array}{l}\text { Outcome of } \\
\text { the study }\end{array}$ \\
\hline Meta-analysis (11) & $\begin{array}{l}27 \text { Eligible studies included } 12,276 \\
\text { cases and } 13,506 \text { controls }\end{array}$ & $\operatorname{Taq} \mathrm{I}$ & $\begin{array}{l}\text { TaqI genotypes TT and TT/Tt were significantly } \\
\text { higher in the advanced prostate cancer } \\
\text { and is associated with the risk in Asians. }\end{array}$ \\
\hline Meta-analysis (13) & $\begin{array}{l}27 \text { Case-control studies with } 10,486 \\
\text { cases and } 10,400 \text { controls }\end{array}$ & FokI & $\begin{array}{l}\text { Overall-no significant association. Significant } \\
\text { association in Caucasian population }\end{array}$ \\
\hline Meta-analysis (18) & 9,720 Patients and 9,710 controls & FokI & $\begin{array}{l}\text { Increased risk of developing prostate } \\
\text { cancer in Caucasian population. }\end{array}$ \\
\hline Meta-analysis (22) & $\begin{array}{c}10 \text { Studies involving } 4979 \text { cases and } 4380 \\
\text { controls }(C d x 2) \text { and } 11 \text { studies involving } \\
2837 \text { cases and } 2884 \text { controls (Apal) }\end{array}$ & $C d x 2, A p a \mathrm{I}$ & $\begin{array}{l}C d x 2 \text { and } A p a I \text { polymorphisms were } \\
\text { not associated with prostate cancer. }\end{array}$ \\
\hline Case-control study (41) & $\begin{array}{l}\text { Peripheral blood of } 342 \text { patients: } 132 \text { PC, } \\
41 \mathrm{BPH} \text { and } 169 \text { young healthy volunteers }\end{array}$ & $\begin{array}{l}\text { FokI, BsmI }, \\
\text { ApaI, TaqI }\end{array}$ & $\begin{array}{l}V D R \text { polymorphism has a genotype- } \\
\text { phenotype association with prostate cancer. }\end{array}$ \\
\hline Case-control study (42) & $\begin{array}{l}124 \text { Jordanian prostate cancer } \\
\text { patients and } 100 \text { healthy volunteers }\end{array}$ & Fok 1 & No significant association \\
\hline Case-control study (43) & $\begin{array}{l}446 \text { AA men aged } 35 \text { to } 93 \text { years and } \\
379 \text { control from AAPCA and Vitamin D and } \\
\text { Prostate Cancer Risk in AA Men Study }\end{array}$ & $\begin{array}{l}\text { rs } 731236, \text { rs } 7975232 \\
\text { rs731236, rs } 1544410 \\
\text { rs } 3782905, \text { rs } 1544410 \\
\text { rs } 2239185\end{array}$ & $\begin{array}{c}\text { Significant association between } \\
V D R \text { polymorphism and prostate } \\
\text { cancer risk in African-American men. }\end{array}$ \\
\hline Case-control study (44) & 7,666 Patients and 8,073 controls & BsmI & $\begin{array}{l}\text { Bsm I polymorphism may be related to } \\
\text { prostate cancer in Caucasian descendants. }\end{array}$ \\
\hline Case-control study (45) & $\begin{array}{l}\text { Blood DNA sample from } 50 \text { patients } \\
\text { and } 79 \text { age-qualified controls }\end{array}$ & $\begin{array}{c}\text { FokI, BsmI, } \\
\text { ApaI and Taq } \mathrm{I}\end{array}$ & $\begin{array}{l}\mathrm{A} \text { and } \mathrm{B} \text { alleles of the VDR ApaI and } B s m \mathrm{I} \\
\text { loci are associated with risk of prostate cancer }\end{array}$ \\
\hline
\end{tabular}

AA: African-American, AAPCA: African-American Sporadic Prostate Cancer Study; BPH: benign prostate hypertrophy.

and $\operatorname{poly}(\mathrm{A})$ on development of breast cancer from 1996 to 2015 and suggested that due to the inconsistent results of various studie, no conclusive evidence associates the risk of breast cancer with VDR polymorphism (32). Similarly, the inconsistent results of the studies shown in Table I suggest the need for further research.

\section{Prostate Cancer}

Prostate cancer is the most common malignant tumor in older men across the globe. The incidence of prostate cancer is increasing worldwide while ethnic origin, family history, hormonal status, dietary structure, age and low vitamin D levels are risk factors for prostate cancer $(36,37)$. Furthermore, studies have reported the association between $V D R$ polymorphism with an increased risk of prostate cancer $(36,38)$. However, the results of various studies were disputable and contradictory (39, $40)$. Most of the studies found no association between VDR polymorphism and prostate cancer $(13,22)$, however, Nunes et al. found correlation between CC genotype (TaqI) with age ( $>58$ years old), and GG (BsmI) with lower prostate-specific antigen (PSA) levels $(<10 \mathrm{ng} / \mathrm{ml})$ (41). Aassociation between a significantly increased estimated chance of PSA $<10 \mathrm{ng} / \mathrm{ml}$ with $\mathrm{G}$ allele $(B s m \mathrm{I})$ and 9.75-fold increased chance of patients with prostate cancer having a lower PSA level with $\mathrm{GG} / \mathrm{GG}$ genotype (BsmI/ApaI) was also found. Recently, various metaanalysis and case-control studies have been conducted to find a relation between VDR polymorphism (TaqI, FokI, Cdx2, ApaI, BsmI, rs731236, rs7975232, rs731236, rs1544410, rs3782905, rs1544410, and rs2239185) and risk of prostate cancer $(11,13$, 18, 22, 41-44). VDR polymorphism FolkI, $C d x 2$, and ApaI were not found to have any association with an increased risk of prostate cancer. VDR polymorphism TaqI, BsmI, rs731236, rs7975232, rs731236, rs1544410, rs3782905, rs1544410, and rs2239185 were found associated with increased risk of prostate cancer (Table II). However, the association varies with race (Asian, Caucasian, and African-American) and the genotypephenotype-based relationship of VDR. Recently, a case-control study investigating the possible associations of $V D R$ polymorphism (FokI, BsmI, ApaI and TaqaI), and the cytochrome $P$-45017 alpha (CYP17) gene (the MspA1I locus) with prostate cancer among Lebanese men suggested that the overall polymorphism profile of every gene involved in prostate physiology is a better indicator than polymorphisms in individual genes (45).

\section{Cancer of the Gastrointestinal Tract}

An array of epidemiological studies have shown that vitamin D protects cells from carcinogenesis in several solid tumors; 
however, recent elucidation concerning the possible deleterious effect of high vitamin $\mathrm{D}$ levels in the development of EAC has raised concern in this field. VDR polymorphism (rs10735810) representing to a T-to-C transition (ATG to $\mathrm{ACG}$ ) in exon 2 of the $V D R$ gene has been associated with gastric cancer in Chinese Han population (46). The role of $V D R$ polymorphisms in relation to the risk of Barrett's oesophagus and EAC has been robustly investigated. Barrett's oesophagus is characterized by highly dysplastic columnar squamous epithelium near the gastro-oesophageal junction and has been deemed a precursor to EAC. Janmaat et al. in a meta-analysis found that $V D R$ haplotype rs2238135G allele is associated with reduced oesophageal VDR expression and a reduced incidence of gastroesophageal reflux disease (GERD), Barrett's oesophagus and EAC (12). In another study, 15 haplotype SNPs of the VDR gene were analyzed in patients with GERD, Barrett's oesophagus or EAC paired with normal histological controls (12). The results demonstrated that there is higher $V D R$ gene expression in tissue from Barrett's oesophagus compared to healthy control samples. A specific SNP was identified in the VDR gene and patients with this haplotype had a two-fold reduced risk of GERD, Barrett's oesophagus and EAC (12) (Table III). The mutated allele was found to cause the appearance of a GATA1 binding site. GATA-1 turns off transcription, which could explain how the presence of a mutated $V D R$ gene would suppress inflammation and rapid cell proliferation in that region (47). The relationship between vitamin D and oesophageal cancer is essentially the opposite to that seen in other cancerous conditions. Whereas abundant and highly functioning vitamin D/VDR pathways are seen to reduce cancer risk, the likelihood of oesophageal cancer and its affiliated precursor diseases is heightened with robust vitamin D pathway activity. Another meta-analysis also found a significant association of reduced risk of oesophageal cancer with VDR SNPs, suggesting that a dysfunctional vitamin D network is advantageous in oesophageal cancer (48). Understanding the mechanisms of action of the $V D R$ haplotype in oesophageal cancer could be of clinical utility by identifying patients in whom vitamin $\mathrm{D}$ chemoprevention would be efficacious. One of the potential explanations for the inverse relationship seen between vitamin $D$ and oesophageal cancer is that $V D R$ has been recently characterized as a bile acid receptor in addition to its wellcharacterized role as a vitamin receptor. Reflux of bile acid into the most distal parts of the oesophagus is one of the pervasive causes of dysplastic progression into EAC $(48,49)$.

Vitamin D plays a crucial role in the pathogenesis of colorectal cancer and epidemiological research has put forth evidence that vitamin $D$ plays a protective role against colorectal cancer (50). The role of polymorphisms of $V D R$ and CYP27B2 and CYP24A1, which are involved in the production and suppression of vitamin $\mathrm{D}$, have all been linked to colorectal cancer risk (51). Similarly, a randomized clinical trial conducted with 2259 patients for 41 SNPs of seven genes [VDR, gene encoding vitamin D-binding protein previously known as gc-globulin $(G C), 7$-dehydrocholesterol reductase (DHCR7), CYP2R1,CYP27B1,CYP24A1 and calcium-sensing receptor $(C A S R)]$ concluded that VDR genotype may influence the prevention of advanced colorectal adenomas with vitamin $\mathrm{D}_{3}$ supplementation, suggesting the role of $V D R$ in colorectal carcinoma (52). Another study in Japan found an association between common genetic variations in $V D R$ and risk of colorectal cancer. The researchers selected $29 V D R$ SNPs and concluded a limited association existed between $V D R$ polymorphism and risk of colorectal cancer (53). Furthermore, another cohort study suggested little effect of the variants in the $V D R$ gene on the risk of colorectal cancer (54). Adenomatous polyps are the precursor for colorectal cancer and a study found FokI to be associated with modified risk for adenomatous polyps in males and association of BsmI/ApaI/TaqI haplotype in females (55). The inconsistent results for the association between $V D R$ polymorphism and risk of colorectal cancer indicate the need for further research as well as epidemiological studies in larger cohorts (Table III).

\section{Skin Cancer}

The protective effect of vitamin D against ultraviolet radiation-induced DNA damage and skin cancer development and the protective role of vitamin D in reducing skin cancer have been discussed. However, the association between vitamin $\mathrm{D}$ and the risk of skin cancer, including melanoma and keratinocyte carcinoma, is still unclear. Vitamin D intake has been positively associated with risk of basal cell carcinoma and melanoma, while non-statistically significantly reducing the incidence of squamous cell carcinoma and melanoma $(61,62)$. The main risk factors associated with skin cancers are sun exposure and skin phototype, anticarcinogenic and procarcinogenic effects of vitamin D. Along with these factors, VDR polymorphism is also involved in the pathogenesis of skin cancer and may increase the susceptibility for malignancy (14). The association of Fok1, Taq1, Apa 1, and Bsm 1 polymorphisms with skin cancer including the studies up to 2014 has been discussed by Ombra et al. (63). Recent studies have suggested VDR polymorphism as a risk factor for skin malignancies $(14,15)$ (Table IV). A meta-analysis showed that $V D R$ polymorphism is associated with the risk of keratinocyte cancer, while rs2228570, rs927650 and rs1544410 recessive genotypes are associated with a reduced risk of squamous cell carcinoma. $V D R$ rs7975232 and rs739837 recessive genotypes were also associated with a reduced risk of basal cell carcinoma (14). Another study 
Table III. Vitamin D receptor (VDR) polymorphisms and cancer of the gastrointestinal tract.

\begin{tabular}{|c|c|c|c|c|}
\hline Type of study & Cancer type & $\begin{array}{l}\text { Number of study } \\
\text { subjects }\end{array}$ & $\begin{array}{l}\text { Polymorphism } \\
\text { under study }\end{array}$ & $\begin{array}{l}\text { Outcome of } \\
\text { the study }\end{array}$ \\
\hline Case-control study (12) & EAC & $\begin{array}{l}858 \text { Patients with GERD, BE or } \\
\text { EAC and } 202 \text { healthy controls }\end{array}$ & $\begin{array}{l}\mathrm{rs} 1989969 \mathrm{~T} / \\
\mathrm{rs} 2238135 \mathrm{G}\end{array}$ & $\begin{array}{l}\text { rs } 1989969 \mathrm{~T} / \mathrm{rs} 2238135 \mathrm{G} \text { is associated } \\
\text { with two-fold lower risk of RE (GERD), } \\
\text { BE, and EAC and lower VDR expression }\end{array}$ \\
\hline Case-control study (56) & ESCC & $\begin{array}{l}582 \text { Patients with ESCC } \\
\text { and } 569 \text { controls }\end{array}$ & $\begin{array}{l}\text { rs2296241, } \\
\text { rs11568820, } \\
\text { rs } 4646536\end{array}$ & $\begin{array}{l}\text { rs } 11568820 \text { is significantly } \\
\text { associated with ESCC cancer. }\end{array}$ \\
\hline Meta-analysis (21) & $\mathrm{CRC}$ & $\begin{array}{l}73 \text { Independent studies including } \\
35,525 \text { cases and } 38,675 \text { controls }\end{array}$ & $\begin{array}{l}\text { TaqI, ApaI, } \\
\text { and Cdx2 }\end{array}$ & $\begin{array}{l}\text { TaqI associated with a significant } \\
\text { increased risk for CRC. }\end{array}$ \\
\hline Case-control study (46) & Gastric & 187 Patients and 212 healthy controls & $\begin{array}{c}\text { FokI } \\
(\text { rs10735810) }\end{array}$ & $\begin{array}{l}\text { f Allele is associated with } \\
\text { susceptibility to gastric cancer and } \\
\text { F allele may be protective. }\end{array}$ \\
\hline Case-control study (51) & $\mathrm{CRC}$ & $\begin{array}{l}152 \text { Patients with CRC } \\
\text { and } 321 \text { controls }\end{array}$ & BsmI and ApaI & $\begin{array}{l}\text { ApaI polymorphisms } \\
\text { increase the risk of CRC. }\end{array}$ \\
\hline $\begin{array}{l}\text { Randomized control } \\
\text { trial (52) }\end{array}$ & $\mathrm{CRC}$ & 2259 Patients & $\begin{array}{l}\text { rs7968585 } \\
\text { rs731236 }\end{array}$ & $\begin{array}{l}\text { VDR genotype may affect } \\
\text { adenoma treatment. }\end{array}$ \\
\hline Case-control study (53) & $\mathrm{CRC}$ & $\begin{array}{l}356 \mathrm{CRC} \text { cases and } \\
709 \text { matched controls }\end{array}$ & $\begin{array}{l}\text { rs2254210, rs } 1540339, \\
\text { rs2107301, rs11168267, } \\
\text { rs11574113, rs731236, } \\
\text { rs3847987 rs11574143 }\end{array}$ & $\begin{array}{l}\text { Limited association of } V D R \\
\text { polymorphism with CRC. }\end{array}$ \\
\hline Case-control study (54) & $\mathrm{CRC}$ & $\begin{array}{l}1,012 \mathrm{CRC} \text { cases and } \\
1,080 \text { controls }\end{array}$ & 35 VDR variants & $\begin{array}{c}\text { Little effect of } V D R \\
\text { variants and risk of CRC. }\end{array}$ \\
\hline Case-control study (57) & CRC & $\begin{array}{l}100 \text { Patients with CRC and } \\
100 \text { healthy age- and gender- } \\
\text { matched controls }\end{array}$ & $\begin{array}{l}\text { BsmI }, \text { FokI, } \\
\text { ApaI and TaqI }\end{array}$ & $\begin{array}{l}\text { ApaI and BsmI loci are significantly } \\
\text { associated with CRC in elderly } \\
\text { and female patients, respectively. }\end{array}$ \\
\hline Hospital based study (55) & AP & $\begin{array}{l}\text { Blood from } 258 \\
\text { colonoscopy patients }\end{array}$ & $\begin{array}{l}\text { Taql, Apal, } \\
\text { FokI, Bsm I }\end{array}$ & $\begin{array}{l}\text { Sex-specific relationship between } \\
\text { these polymorphisms and } \\
\text { risk for adenomatous polyp. }\end{array}$ \\
\hline Case-control study (58) & Pancreatic & $\begin{array}{l}3,583 \text { Pancreatic cancer } \\
\text { cases and } 7,053 \text { controls }\end{array}$ & $\begin{array}{l}\text { rs2239186, rs } 7967152 \\
\text { rs12721364 }\end{array}$ & $\begin{array}{l}\text { rs } 2239186 \text { is associated with risk of } \\
\text { pancreatic cancer but not significant. }\end{array}$ \\
\hline Cohort analysis (59) & Pancreatic & $\begin{array}{l}493 \text { Patients from five } \\
\text { prospective US cohorts }\end{array}$ & 30 SNPs & $\begin{array}{l}\text { No significant association between } V D R \\
\text { polymorphism and pancreatic cancer. }\end{array}$ \\
\hline Case-control study (60) & $\mathrm{HCC}$ & $\begin{array}{l}35 \text { Patients with HCC with } \\
\text { HCV and } 45 \\
\text { healthy controls }\end{array}$ & $\begin{array}{l}B s m \mathrm{I}(\mathrm{G} / \mathrm{A}) \\
\text { polymorphism } \\
(\mathrm{rs} 1544410)\end{array}$ & $\begin{array}{l}\text { No significant influence on } \\
\text { susceptibility to HCC. }\end{array}$ \\
\hline
\end{tabular}

AP: Adenomatous polyp; BE: Barrett's esophagus, CRC: colorectal cancer; ESCC: esophageal squamous cell carcinoma; EAC: esophageal adenocarcinoma; GERD: gastro-esophageal reflux disease, HCC: hepatocellular carcinoma; HBV: hepatitis B virus; HCV: hepatitis C virus; RE: reflux esophagitis.

found an association of Bsml polymorphism with melanoma in Europeans (15). Furthermore, a meta-analysis by Orlow et al. found a significant association between VDR polymorphism and melanoma-specific survival, however, no significant association was found between Breslow thickness, ulceration or mitosis, and VDR polymorphism (64). These results suggest the need for more research.

\section{Urinary Tract Cancer}

Vitamin D and VDR are involved in cell division, cell adhesion, and cell function. A normal renal function is necessary for vitamin D metabolism. The role of vitamin D, VDR, and retinoid-X-receptor in inhibition of cell proliferation and angiogenesis and induction of differentiation and apoptosis, and in the pathogenesis of renal cell carcinoma (RCC) has been discussed. Both low and high levels of circulating vitamin $\mathrm{D}$ have been associated with higher risk of death from any cause among RCC cases (66-68). This indicates that vitamin D levels may affect the pathogenesis of RCC and VDR might be involved in RCC carcinogenesis. Recent case-control studies by Yang et al. (66) and Pospiech et al. (69) suggest the association of increased risk of RCC with $V D R$ polymorphism. There is experimental and epidemiological evidence that vitamin $\mathrm{D}$ has a protective role against bladder cancer, however, the causal relationship is unclear $(2,70,71)$. Studying $V D R$ polymorphisms may elucidate the causal relationship of bladder cancer. Recently, 
Table IV. Vitamin D receptor (VDR) polymorphisms and skin cancer.

\begin{tabular}{|c|c|c|c|c|}
\hline Type of study & Cancer type & $\begin{array}{c}\text { Number of study } \\
\text { subjects }\end{array}$ & $\begin{array}{l}\text { Polymorphism } \\
\text { under study }\end{array}$ & $\begin{array}{l}\text { Outcome of } \\
\text { the study }\end{array}$ \\
\hline $\begin{array}{l}\text { Case-control study } \\
\text { and Meta-analysis (14) }\end{array}$ & $\mathrm{SCC}, \mathrm{BCC}$ & $\begin{array}{c}\text { 1,124 Adults in } \\
\text { 11-year follow-up. } \\
\text { Associations with incidence } \\
\text { of keratinocyte cancer }\end{array}$ & $\begin{array}{l}\text { rs } 2228570, \text { rs } 7975232, \\
\text { rs1544410, rs } 739837\end{array}$ & $\begin{array}{l}\text { rs } 2228570, \text { rs } 1544410, \text { and rs } 927650 \\
\text { are associated with a reduced risk } \\
\text { of SCC and rs7975232 and rs } 739837 \\
\text { with a decreased risk of BCC }\end{array}$ \\
\hline Meta-analysis (15) & Melanoma & $\begin{array}{l}11 \text { Studies including } 4,413 \\
\text { patients and } 4,072 \\
\text { controls (all European). }\end{array}$ & $\begin{array}{l}\text { FokI, BsmI, TaqI, } \\
\text { ApaI, and EcoRV }\end{array}$ & $\begin{array}{l}\text { BsmI polymorphism is associated } \\
\text { with susceptibility to melanoma } \\
\text { in Europeans, BsmI B allele } \\
\text { may be a protective factor. }\end{array}$ \\
\hline $\begin{array}{l}\text { Multi-center population } \\
\text {-based study of } \\
\text { melanoma (64) }\end{array}$ & Melanoma & $\begin{array}{l}3566 \text { Incident single } \\
\text { and multiple } \\
\text { primary melanoma. }\end{array}$ & $\begin{array}{l}\text { rs } 7299460, \text { rs } 3782905, \\
\text { rs } 2239182, \text { rs } 12370156, \\
\text { rs2238140, rs } 7305032, \\
\text { BsmI (rs1544410), } \\
\text { TaqI (rs731236) }\end{array}$ & $\begin{array}{c}\text { All significantly associated with } \\
\text { melanoma-specific survival but } \\
\text { not with Breslow thickness, } \\
\text { ulceration or mitosis. }\end{array}$ \\
\hline Meta-analysis (65) & Melanoma & $\begin{array}{l}10 \text { studies including } 4,961 \\
\text { melanoma patients and } \\
\text { 4,605 controls. }\end{array}$ & $\begin{array}{c}\text { Apa1, Bsm } 1, C d x 2 \\
\text { EcoRV, Fok } 1 \\
\text { and Taq } 1\end{array}$ & $\begin{array}{c}\text { Fok } 1 \text { and } B s m 1 \text { may influence } \\
\text { susceptibility to } \\
\text { developing melanoma. }\end{array}$ \\
\hline
\end{tabular}

BCC: Basal cell carcinoma; SCC: squamous cell carcinoma.

Ben Fradj et al. suggest that ff genotype and $\mathrm{f}$ allele of FokI polymorphism are associated with increased risk of urothelial bladder cancer (70). Furthermore, the associations of ApaI, BsmI, Fok1, and Taq1 polymorphisms with RCC and prostate cancer, Fok1 with bladder cancer, $V D R$ in relation to testicular cancer and testicular germ cell tumors have been reviewed (2). The results of the studies reported in Table V suggest that $V D R$ polymorphisms may be risk factors for urological cancer. However, due to the limited number of studies, the evidence for a clear association between urological cancer and $V D R$ polymorphism is not concrete and more epidemiological studies needed.

\section{Paediatric Tumors}

Vitamin D plays a crucial role in regulating cellular homeostasis and proliferation. The role of vitamin D in the pathogenesis of various cancer types has been discussed in the literature as described above in relation to breast, prostate, gastric, and colorectal, etc. in adults. Vitamin D deficiency has been associated with increased prevalence of childhood cancer $(72,73)$. Vitamin D also plays a role in bone homeostasis and metabolism and its deficiency play a role in inflammation and the pathogenesis of osteoporosis and osteoarthritis (74). Furthermore, the association of osteosarcoma and Ewing sarcoma with a significantly higher frequency of the Ff genotype for the FokI polymorphism suggests the role of $V D R$ polymorphism in bone tumors (75). In a pediatric population, no association of $V D R$ polymorphism and Hodgkin's lymphoma was found (76).
However, in the case of pediatric solid tumors, a weak association between CT and CC genotype of FokI with reduced risk of pediatric solid cancer occurrence was reported (24). Moreover, the association of VDR polymorphic variant $\mathrm{rs} 1544410$ with minimal residual disease in pediatric B-cell precursor acute lymphoblastic leukaemia at day 15 suggests a prognostic value as well as the pathogenic role of this VDR polymorphism (77). Furthermore, the case-control studies in Table VI suggest that $V D R$ polymorphism has an association with reduced pediatric solid tumors (FokI), no association with Hodgkin's lymphoma, and may affect bone mineral density, patient height and overall survival. Vitamin D level and VDR expression may also serve as predictors for the occurrence and overall survival of solid tumors in the pediatric population $(24,75,76,78)$. The effects of $V D R$ polymorphisms on tumourigenesis and other parameters indicate the need for deeper research into the role of $V D R$ polymorphisms and their effects on vitamin D metabolism pertains to the human physiology.

\section{Haematological Cancer}

A study on the association of plasmablastic B-cell malignancies including plasmablastic lymphoma, subsets of multiple myeloma, and diffuse large B-cell lymphoma and $V D R$ polymorphism found that the Fok1 polymorphism was associated with greater vitamin D3-dependent tumor growth inhibition. The findings of the study suggest the possible therapeutic benefit of the disruption of the VDR pathway 
Table V. Urinary tract cancer and vitamin D receptor (VDR) polymorphisms.

\begin{tabular}{|c|c|c|c|c|}
\hline Type of study & Cancer type & $\begin{array}{l}\text { Number of study } \\
\text { subjects }\end{array}$ & $\begin{array}{l}\text { Polymorphism } \\
\text { under study }\end{array}$ & $\begin{array}{l}\text { Outcome of } \\
\text { the study }\end{array}$ \\
\hline Case-control study (66) & $\mathrm{RCC}$ & $\begin{array}{c}302 \text { Patients and } 302 \\
\text { healthy controls }\end{array}$ & $\begin{array}{c}\text { TaqI, BsmI , Cdx-2, } \\
\text { ApaI, Fok } \mathrm{I}\end{array}$ & $\begin{array}{c}\text { ApaI genotypes may be associated } \\
\text { with the increased risk and } \\
\text { progression of RCC in } \\
\text { Chinese Han population. }\end{array}$ \\
\hline Case-control study (69) & ccRCC & $\begin{array}{c}167 \text { Patients and } 200 \\
\text { healthy controls }\end{array}$ & $\begin{array}{l}\text { rs } 739837, \text { rs } 731236 \\
\text { rs } 7975232, \text { rs } 1544410\end{array}$ & $\begin{array}{l}V D R \text { polymorphism is associated } \\
\text { with increased risk of ccRCC. }\end{array}$ \\
\hline Case-control study (70) & $\mathrm{UBC}$ & $\begin{array}{l}200 \text { unrelated Tunisian } \\
\text { patients and } 200 \text { healthy controls }\end{array}$ & FokI & $\begin{array}{l}\text { ff Genotype and f allele were associated } \\
\text { with increased risk of UBC in ever-smokers. }\end{array}$ \\
\hline
\end{tabular}

ccRCC: Clear cell renal cell carcinoma; RCC: renal cell carcinoma; UBC: urothelial bladder cancer.

Table VI. Vitamin D receptor (VDR) polymorphisms and paediatric tumors.

\begin{tabular}{|c|c|c|c|c|}
\hline Type of study & Cancer type & $\begin{array}{l}\text { Number of study } \\
\text { subjects }\end{array}$ & $\begin{array}{l}\text { Polymorphism } \\
\text { under study }\end{array}$ & $\begin{array}{l}\text { Outcome of } \\
\text { the study }\end{array}$ \\
\hline Case-control study (24) & Solid tumors & $\begin{array}{l}111 \text { Pediatric patients and } \\
787 \text { adults as control }\end{array}$ & $\begin{array}{c}\text { BsmI }(\mathrm{rs} 1544410 ; \\
\mathrm{A}>\mathrm{G}), \text { Fok } \\
(\mathrm{rs} 2228570 ; \mathrm{C}>\mathrm{T}), \\
\text { TaqI }(\mathrm{rs} 731236 ; \mathrm{T}>\mathrm{C}), \\
\text { ApaI }(\mathrm{rs} 7975232 ; \\
\mathrm{C}>\mathrm{T}) \mathrm{Cdx}-2 \\
(\mathrm{rs} 11568820 ; \mathrm{A}>\mathrm{G})\end{array}$ & $\begin{array}{l}\text { FokI was associated with } \\
\text { lower risk of cancer. }\end{array}$ \\
\hline Case-control study (76) & $\mathrm{HL}$ & $\begin{array}{l}95 \text { Cases with } 100 \\
\text { healthy controls }\end{array}$ & $\begin{array}{c}C d x 2, \text { Fok } 1, \text { Bsm } 1, \\
\text { Apa } 1, \text { and Taq } 1\end{array}$ & No association with HL. \\
\hline Single-center study (78) & ALL & $\begin{array}{c}40 \text { Newly } \\
\text { diagnosed cases }\end{array}$ & $\begin{array}{l}\text { BsmI (rs1544410), } \\
\text { ApaI (rs739837), } \\
\text { TaqI (rs731236), } \\
\text { Cdx2 (rs11568820) } \\
\text { GATA (rs4516035) }\end{array}$ & $\begin{array}{c}\text { TaqI }(\mathrm{Tt}) \text { was significantly correlated } \\
\text { with high BMD in ALL and } \\
\text { Bsm }(\mathrm{Bb}) \text { was related to higher } \\
\text { BMD in ALL Egyptian } \\
\text { paediatric population. }\end{array}$ \\
\hline
\end{tabular}

ALL: Acute lymphoblastic leukaemia; BMD: bone mineral density; HL: Hodgkin’s lymphoma.

activity in order to enhance susceptibility to vitamin D treatment in these malignancies (79). Another study in a Chinese Han population on the association of VDR polymorphisms rs2228570 (FokI) and rs731236 (TaqI) and multiple myeloma susceptibility including 113 patients and 117 healthy controls reported that rs2228570 TT genotype and mutant $\mathrm{C}$ allele of rs731236 are significantly associated with increased risk of multiple myeloma. The study concluded that the polymorphisms rs2228570 and rs731236 might be important genetic factors in the susceptibility to multiple myeloma (80). Esfahani et al. studied the association of VDR polymorphisms (FokI, BsmI, TaqI and $A p a \mathrm{I})$ with acute myeloid leukaemia involving 133 patients and 300 controls and found a significant association between VDR polymorphism and acute myeloid leukaemia, and association of Taql with complete remission (81).

\section{Additional Cancer-related Interactions of $V D R$ polymorphisms}

Along with cancer of female genital tract, prostate, gastrointestinal tract, urological tumors, skin cancer, and pediatric tumors, $V D R$ polymorphisms may also play a role in the carcinogenesis of lung and thyroid cancer. A casecontrol study including 426 patients with non-small cell lung cancer (NSCLC) and 445 controls from China studying $V D R$ polymorphisms rs1544410 and rs731236 found a statistically significant relation between $V D R$ polymorphism and reduction in NSCLC risk (82). Furthermore, the association of increased $V D R$ mRNA expression with worse prognostic factors in papillary thyroid carcinoma suggests the role of VDR in thyroid cancer (83). Since vitamin D deficiency is associated with thyroid diseases and its 
metabolism is regulated by thyroid hormone, $V D R$ polymorphism may play a role in pathogenesis and prognosis of thyroid cancer (84). A recent meta-analysis found a clear and strong association between low levels of baseline vitamin D and poorer survival and an association between $V D R$ genetic variants and survival [rs7975232 (ApaI) with progression-free survival; rs1544410 (BsmI) with overall survival; and rs2228570 (FokI) with overall survival] in lung cancer. However, from all the observational studies included in this meta-analysis, a causal relationship was not conclusively established (85).

\section{Conclusion}

The results of various studies suggest the crucial role of $V D R$ polymorphism (mainly FokI, ApaI, BsmI, and TaqI) in tumorigenesis of various cancer types by affecting vitamin D metabolism and the cellular response to vitamin D. From the above-discussed studies, it is also obvious that the association between VDR polymorphism and tumorigenesis varies with age, sex, race and ethnicity. The results of these studies also suggest that studying $V D R$ polymorphisms in order to strengthen our understanding of the vitamin $D$ pathway could provide additional evidence for its protective therapeutic role against cancer development $(33,79)$. VDR polymorphisms might also serve as indicators for diagnosis, occurrence, and prognosis as well as survival in cancer (24, $64,75-78,83-85)$. There have been many epidemiological studies of breast, prostate and colorectal cancer, however, there are limited reports on the association of $V D R$ polymorphism with lung, thyroid, oesophageal, ovarian, renal and hepatocellular carcinoma. These studies have shown the association of $V D R$ polymorphism with increased risk of cancer, reduced risk of cancer, as well as no association. Thus, there is a need for more studies with larger cohorts in order to establish the significant associations and causal relationships between $V D R$ polymorphism and cancer. Additionally, genetic variation in the vitamin D pathway should be considered when designing potential intervention strategies with vitamin D supplementation.

\section{Financial and Competing Interest Disclosure}

The Authors have no other relevant affiliations or financial involvement with any organization or entity with the financial interest or financial conflict with the subject matter or materials discussed in the manuscript apart from those disclosed. No writing assistance was utilized in the production of this article.

\section{Acknowledgements}

This work was supported by research grants R01 HL116042, R01 HL112597, and R01 HL120659 to DK Agrawal from the National Heart, Lung and Blood Institute, National Institutes of Health, USA.
The content of this review article is solely the responsibility of the Authors and does not necessarily represent the official views of the National Institutes of Health.

\section{References}

1 Trowbridge R, Kizer RT, Mittal SK and Agrawal DK: 1,25Dihydroxyvitamin D in the pathogenesis of Barrett's esophagus and esophageal adenocarcinoma. Expert Rev Clin Immunol 9: 517-533, 2013

2 Krajewski W, Dziegala M, Kolodziej A, Dembowski J and Zdrojowy R: Vitamin D and urological cancers. Cent European J Urol 69: 139-147, 2016.

3 Elzehery RR, Baiomy AA, Hegazy MAF, Fares R, El-Gilany AH and Hegazi R: Vitamin D status, receptor gene BsmI (A/G) polymorphism and breast cancer in a group of Egyptian females. Egypt J Med Hum Genet, 2016. doi.org/10.1016/ j.ejmhg.2016.11.003. [Epub ahead of print]

4 Zhang K and Song L: Association between vitamin D receptor gene polymorphisms and breast cancer risk: a meta-analysis of 39 studies. PLoS One 9: e96125, 2014.

5 Fuhrman BJ, Freedman DM, Bhatti P, Doody MM, Fu YP, Chang SC, Linet MS and Sigurdson AJ: Sunlight, polymorphisms of vitamin D-related genes and risk of breast cancer. Anticancer Res 33: 543-551, 2013.

6 Slatter ML, Yakumo K, Hoffman M and Neuhausen S: Variants of the VDR gene and risk of colon cancer (United States). Cancer Causes Control 12: 359-364, 2001.

7 Denzer N, Vogt T and Reichrath J: Vitamin D receptor (VDR) polymorphisms and skin cancer: A systematic review. Dermatoendocrinol 3: 205-210, 2011.

8 Duffy MJ, Murray A, Synnott NC, O'Donovan N and Crown J: Vitamin D analogues: Potential use in cancer treatment. Crit Rev Oncol Hematol 112: 190-197, 2017.

9 Gandini S, Gnagnarella P, Serrano D, Pasquali E and Raimondi S: Vitamin D receptor polymorphisms and cancer. Adv Exp Med Biol 810: 69-105, 2014.

10 Dai ZM, Fei YL, Zhang WG, Liu J, Cao XM, Qu QM, Li YC, Lin S, Wang M and Dai ZJ: Association of Vitamin D Receptor Cdx-2 Polymorphism With Cancer Risk: A Meta-Analysis. Medicine (Baltimore) 94(33): e1370, 2015.

11 Fei X, Liu N, Li H, Shen Y, Guo J and Wu Z: Polymorphisms of vitamin D receptor gene TaqI susceptibility of prostate cancer: a meta-analysis. Onco Targets Ther 9: 1033-1045, 2016.

12 Janmaat VT, Van De Winkel A, Peppelenbosch MP, Spaander MC, Uitterlinden AG, Pourfarzad F, Tilanus HW, Rygiel AM, Moons LM, Arp PP, Krishnadath KK, Kuipers EJ and Van Der Laan LJ: Vitamin D Receptor Polymorphisms Are Associated with Reduced Esophageal Vitamin D Receptor Expression and Reduced Esophageal Adenocarcinoma Risk. Mol Med 21: 346354, 2015.

13 Kang S, Zhao Y, Liu J, Wang L, Zhao G, Chen X, Yao A, Zhang L, Zhang X and Li X: Association of Vitamin D receptor FokI polymorphism with the risk of prostate cancer: a meta-analysis. Oncotarget 7(47): 77878-77889, 2016.

14 VON Schuckmann LA, Law MH, Montgomery GW, Green AC and VAN DER Pols JC: Vitamin D Pathway Gene Polymorphisms and Keratinocyte Cancers: A Nested CaseControl Study and Meta-Analysis. Anticancer Res 36(5): 21452152, 2016. 
15 Lee YH and Gyu Song G: Vitamin D receptor FokI, BsmI, TaqI, $A p a \mathrm{I}$, and EcoRV polymorphisms and susceptibility to melanoma: a meta-analysis. J BUON 20(1): 235-243, 2015.

16 Li X, Zhang RS, Liu ZK, Li S, Liu L and Xu H: Menopausal status could modify breast cancer risk associated with the FokI polymorphism in vitamin $\mathrm{D}$ receptor gene: a meta-analysis. Int J Clin Exp Med 9(7): 14067-14076, 2016.

17 Lu D, Jing L and Zhang S: Vitamin D Receptor Polymorphism and Breast Cancer Risk: A Meta-Analysis. Medicine (Baltimore) 95(18): e3535, 2016.

18 Mi YY, Chen YZ, Chen J, Zhang LF, Zuo L and Zou JG: Updated analysis of vitamin D receptor gene FokI polymorphism and prostate cancer susceptibility. Arch Med Sci 12(1), 2016. doi: https://doi.org/10.5114/aoms.2016.61793. [Epub ahead of print]

19 Mun MJ, Kim TH, Hwang JY and Jang WC: Vitamin D receptor gene polymorphisms and the risk for female reproductive cancers: A meta-analysis. Maturitas 81(2): 256-265, 2015.

20 Pulito C, Terrenato I, Di Benedetto A, Korita E, Goeman F, Sacconi A, Biagioni F, Blandino G, Strano S, Muti P, Mottolese $\mathrm{M}$ and Falvo E: $C d x 2$ polymorphism affects the activities of vitamin D receptor in human breast cancer cell lines and human breast carcinomas. PLoS One 10(4): e0124894, 2015.

21 Serrano D, Gnagnarella P, Raimondi S and Gandini S: Metaanalysis on vitamin $\mathrm{D}$ receptor and cancer risk: focus on the role of TaqI, ApaI, and $C d x 2$ polymorphisms. Eur J Cancer Prev 25(1): 85-96, 2016.

22 Wang $\mathrm{K}, \mathrm{Wu} \mathrm{G}$, Li J and Song W: Role of vitamin D receptor gene $C d x 2$ and Apa 1 polymorphisms in prostate cancer susceptibility: a meta-analysis. BMC Cancer 16(1): 674, 2016.

23 Al-Azhri J, Zhang Y, Bshara W, Zirpoli G, McCann SE, Khoury T, Morrison CD, Edge SB, Ambrosone CB and Yao S: Tumor Expression of Vitamin D Receptor and Breast Cancer Histopathological Characteristics and Prognosis. Clin Cancer Res 23(1): 97-103, 2017.

24 Bienertova-Vasku J, Drabova K, Zlamal F, Tomandl J, Kyr M, Šplíchal Z and Štěrba J: Pre-treatment VD levels and VDR receptors as potential predictors of occurrence and overall survival in paediatric patients with solid tumours-a single institution pilot study. Tumour Biol 37(7): 9209-9219, 2016.

25 Colagar AH, Firouzjah HM and Halalkhor S: Vitamin D receptor poly(A) microsatellite polymorphism and 25-hydroxyvitamin D serum levels: association with susceptibility to breast cancer. J Breast Cancer 18(2): 119-125, 2015.

26 Haikal NMA, El-Hussiny MA-B, Farouk O and Hashem EMA: Bsm 1 Gene polymorphism of the vitamin D receptor in breast cancer patients: influence of obesity and relevant drugs. Comp Clin Pathol 26(1): 127-134, 2017.

27 Iqbal M, Khan TA and Maqbool SA: Vitamin D receptor Cdx-2 polymorphism and premenopausal breast cancer risk in southern Pakistani patients. PLoS One 10(3): e0122657, 2015.

28 Rashid MU, Muzaffar M, Khan FA, Kabisch M, Muhammad N, Faiz S, Loya A and Hamann U: Association between the BsmI Polymorphism in the Vitamin D Receptor Gene and Breast Cancer Risk: Results from a Pakistani Case-Control Study. PLoS One 10(10): e0141562, 2015.

29 Reimers LL, Crew KD, Bradshaw PT, Santella RM, Steck SE, Sirosh I, Terry MB, Hershman DL, Shane E, Cremers S, Dworakowski E, Teitelbaum SL, Neugut AI and Gammon MD: Vitamin D-related gene polymorphisms, plasma 25-hydroxyvitamin $\mathrm{D}$, and breast cancer risk. Cancer Causes Control 26(2): 187-203, 2015.
30 Shi J, Grundy A, Richardson H, Burstyn I, Schuetz JM, Lohrisch CA, SenGupta SK, Lai AS, Brooks-Wilson A, Spinelli JJ and Aronson KJ: Genetic variation in vitamin D-related genes and risk of breast cancer among women of European and East Asian descent. Tumour Biol 37(5): 6379-6387, 2016.

31 Talaneh S, Ghorbani A, Bakhshaiesh TO and Jafari B: FokI and BsmI Polymorphisms of the VDR gene and breast cancer risk. Multidiscip Cancer Invest 1(1): 21-25, 2017.

32 Shaikh F, Baig S and Jamal Q: Do VDR Gene Polymorphisms Contribute to Breast Cancer? Asian Pac J Cancer Prev 17(2): 479-483, 2016.

33 Amadori D, Serra P, Masalu N, Pangan A, Scarpi E, Bugingo AM, Katabalo D, Ibrahim T, Bongiovanni A, Miserocchi G, Spadazzi C, Liverani C, Turri V, Tedaldi R and Mercatali L: Vitamin D receptor polymorphisms or serum levels as key drivers of breast cancer development? The question of the vitamin D pathway. Oncotarget 8(8): 13142-13156, 2017.

34 Mostowska A, Sajdak S, Pawlik P, Lianeri M and Jagodzinski PP: Polymorphic variants in the vitamin D pathway genes and the risk of ovarian cancer among non-carriers of BRCA1/BRCA2 mutations. Oncol Lett 11(2): 1181-1188, 2016.

35 Shafie F, Dehpour A and Nazari Z: Vitamin D and VDR gene polymorphism FokI and Taq1 in epithelial ovarian cancer in North of Iran. J Fundam Appl Sci 8(3S): 2263-2269, 2016.

36 Oh JJ, Byun SS, Lee SE, Hong SK, Jeong CW, Kim D, Kim HJ and Myung SC: Genetic variations in VDR associated with prostate cancer risk and progression in a Korean population. Gene 533(1): 86-93, 2014.

37 Galunska B, Gerova D, Kosev P, Anakievski D and Hinev A: Serum 25-hydroxy vitamin D levels in Bulgarian patients with prostate cancer: a pilot study. Clin Lab 61(3-4): 329-335, 2015.

38 Cheteri MB, Stanford JL, Friedrichsen DM, Peters MA, Iwasaki L, Langlois $\mathrm{MC}$ and Feng Z: Vitamin D receptor gene polymorphisms and prostate cancer risk. Prostate 59(4): 409418, 2004.

39 Li H, Stampfer MJ, Hollis JB, Mucci LA, Gaziano JM, Hunter D, Giovannucci EL and Ma J: A prospective study of plasma vitamin D metabolites, vitamin D receptor polymorphisms, and prostate cancer. PLoS Med 4(3): e103, 2007.

40 Yousaf N, Afzal S, Hayat T, Shah J, Ahmad N, Abbasi R, Ramzan K, Jan R, Khan I, Ahmed J and Siraj S: Association of vitamin $\mathrm{D}$ receptor gene polymorphisms with prostate cancer risk in the Pakistani population. Asian Pac J Cancer Prev 15(22): 10009-13, 2014.

41 Nunes SB, de Matos Oliveira F, Neves AF, Araujo GR, Marangoni K, Goulart LR and Araújo TG: Association of vitamin $\mathrm{D}$ receptor variants with clinical parameters in prostate cancer. Springerplus 5: 364, 2016.

42 Atoum MF, AlKateeb D and AlHaj Mahmoud SA: The Fok1 vitamin $\mathrm{D}$ receptor gene polymorphism and $25(\mathrm{OH}) \mathrm{D}$ serum levels and prostate cancer among Jordanian men. Asian Pac J Cancer Prev 16(6): 2227-2230, 2015.

43 Jingwi EY, Abbas M, Ricks-Santi L, Winchester D, Beyene D, Day A, Naab TJ, Kassim OO, Dunston GM, Copeland RL Jr. and Kanaan YM: Vitamin D receptor genetic polymorphisms are associated with PSA level, Gleason score and prostate cancer risk in African-American men. Anticancer Res 35(3): 1549-1558, 2015. 
44 Mi YY, Chen YZ, Chen J, Zou JG, Zhang LF, Zuo L, Yasui T and Okada A: Association between vitamin D receptor gene BsmI polymorphism and susceptibility to prostate cancer. Int $\mathbf{J}$ Clin Exp Med 9(2): 2786-2794, 2016.

45 El Ezzi AA, Baker MT, Zaidan WR, Hraiki KM, El Saidi MA and Kuddus RH: Association of polymorphisms in the VDR, CYP17 and SRD5A2 genes and prostate cancer among Lebanese men. Asian Pac J Cancer Prev 18(1): 93-100, 2017.

46 Cong L, Wang WB, Liu Q and Du JJ: FokI Polymorphism of the vitamin D receptor gene is associated with susceptibility to gastric cancer: A case-control study. Tohoku J Exp Med 236(3): 219-224, 2015.

47 Kuo YY and Chang ZF: Correction for Kuo and Chang, GATA1 and Gfi-1B Interplay to Regulate Bcl-xL Transcription. Mol Cell Biol 37(6): e00008-17, 2017.

48 Zgaga L, O'Sullivan F, Cantwell MM, Murray LJ, Thota PN and Coleman HG: Markers of vitamin D exposure and esophageal cancer risk: a systematic review and meta-analysis. Cancer Epidemiol Biomarkers Prev 25(6): 877-886, 2016.

49 Copple BL and $\mathrm{Li} \mathrm{T}$ : Pharmacology of bile acid receptors: Evolution of bile acids from simple detergents to complex signaling molecules. Pharmacol Res 104: 9-21, 2016.

50 Bandera Merchan B, Morcillo S, Martin-Nunez G, Tinahones FJ and Macias-Gonzalez M: The role of vitamin D and VDR in carcinogenesis: Through epidemiology and basic sciences. J Steroid Biochem Mol Biol 167: 203-218, 2017.

51 Vidigal VM, Silva TD, de Oliveira J, Pimenta CAM, Felipe AV and Forones NM: Genetic polymorphisms of vitamin D receptor (VDR), CYP27B1 and CYP24A1 genes and the risk of colorectal cancer. Int J Biol Markers 32(2): e224-e230, 2017.

52 Barry EL, Peacock JL, Rees JR, Bostick RM, Robertson DJ, Bresalier RS, Baron JA: Vitamin D receptor genotype, vitamin D3 supplementation, and risk of colorectal adenomas: a randomized clinical trial. JAMA Oncol 3(5): 628-635, 2017.

53 Budhathoki S, Yamaji T, Iwasaki M, Sawada N, Shimazu T, Sasazuki S, Yoshida T and Tsugane S: Vitamin D receptor gene polymorphism and the risk of colorectal cancer: a nested casecontrol study. PLoS One 11(10): e0164648, 2016.

54 Ashmore JH, Gallagher CJ, Lesko SM, Muscat JE, Hartman TJ and Lazarus P: No Association Between Vitamin D Intake, VDR polymorphisms, and colorectal cancer in a population-based case-control study. Cancer Epidemiol Biomarkers Prev 24(10): 1635-1637, 2015.

55 Beckett EL, Le Gras K, Martin C, Boyd L, Ng X, Duesing K, Yates Z, Veysey $\mathrm{M}$ and Lucock $\mathrm{M}$ : Vitamin $\mathrm{D}$ receptor polymorphisms relate to risk of adenomatous polyps in a sexspecific manner. Nutr Cancer 68(2): 193-200, 2016.

56 Yang J, Wang H, Ji A, Ma L, Wang J, Lian C, Wei Z and Wang L: Vitamin D Signaling Pathways confer the susceptibility of esophageal squamous cell carcinoma in a Northern Chinese population. Nutr Cancer 69(4): 593-600, 2017.

57 Alkhayal KA, Awadalia ZH, Vaali-Mohammed MA, Al Obeed OA, Al Wesaimer A, Halwani R, Zubaidi AM, Khan Z, Abdulla MH: Association of vitamin D receptor gene polymorphisms with colorectal cancer in a Saudi Arabian population. PLoS One 11(6): e0155236, 2016.

58 Arem H, Yu K, Xiong X, Moy K, Freedman ND, Mayne ST, Albanes D, Arslan AA, Austin M, Bamlet WR, Beane-Freeman L, Bracci P, Canzian F, Cotterchio M, Duell EJ, Gallinger S, Giles GG, Goggins M, Goodman PJ, Hartge P, Hassan M,
Helzlsouer K, Henderson B, Holly EA, Hoover R, Jacobs EJ, Kamineni A, Klein A, Klein E, Kolonel LN, Li D, Malats N, Männistö S, McCullough ML, Olson SH, Orlow I, Peters U, Petersen GM, Porta M, Severi G, Shu XO, Visvanathan K, White E, Yu H, Zeleniuch-Jacquotte A, Zheng W, Tobias GS, Maeder D, Brotzman M, Risch H, Sampson JN and StolzenbergSolomon RZ: Vitamin D metabolic pathway genes and pancreatic cancer risk. PLoS One 10(6): e0117574, 2015.

59 Yuan C, Qian ZR, Babic A, Morales-Oyarvide V, Rubinson DA, Kraft P, Ng K, Bao Y, Giovannucci EL, Ogino S, Stampfer MJ, Gaziano JM, Sesso HD, Buring JE, Cochrane BB, Chlebowski RT, Snetselaar LG, Manson JE, Fuchs CS and Wolpin BM: Prediagnostic plasma 25-hydroxyvitamin D and pancreatic cancer survival. J Clin Oncol 34(24): 2899-2905, 2016.

60 Youssef EM, Mohamed FS, Edreis AE, Sedik WF, Alblihed MA, Soliman AA, Elsaid Tash RM, M. Ahmed NH, Hassan MM, ElFedawy El-Saied M, Elkady MM and Elhakeem H: Evaluation of OPN level and VDR gene polymorphism in patients with hepatocellular carcinoma. Res Cancer and Tumor 5(1): 10-16, 2016.

61 van der Pols JC, Russell A, Bauer U, Neale RE, Kimlin MG and Green AC: Vitamin D status and skin cancer risk independent of time outdoors: 11-year prospective study in an Australian community. J Invest Dermatol 133(3): 637-641, 2013.

62 Park SM, Li T, Wu S, Li WQ, Qureshi AA and Cho E: Vitamin $\mathrm{D}$ intake and risk of skin cancer in US women and men. PLoS One 11(8): e0160308, 2016.

63 Ombra MN, Paliogiannis P, Doneddu V, Sini MC, Colombino M, Rozzo C, Stanganelli I, Tanda F, Cossu A and Palmieri G: Vitamin D status and risk for malignant cutaneous melanoma: recent advances. Eur J Cancer Prev, 2017. doi: 10.1097/CEJ.00 00000000000334. [Epub ahead of print]

64 Orlow I, Reiner AS, Thomas NE, Roy P, Kanetsky PA, Luo L, Paine S, Armstrong BK, Kricker A, Marrett LD, Rosso S, Zanetti R, Gruber SB, Anton-Culver H, Gallagher RP, Dwyer T, Busam K, Begg CB and Berwick M; GEM Study Group: Vitamin D receptor polymorphisms and survival in patients with cutaneous melanoma: a population-based study. Carcinogenesis 37(1): 30-38, 2016.

65 Hou W, Wan X and Fan J: Variants Fok1 and Bsm1 on VDR are associated with the melanoma risk: evidence from the published epidemiological studies. BMC Genet 16: 14, 2015.

66 Yang C, Li J, Li Y, Wu D, Sui C, Jiang Y and Meng F: The vitamin $\mathrm{D}$ receptor gene ApaI polymorphism is associated with increased risk of renal cell carcinoma in Chinese population. Sci Rep 6: 25987, 2016.

67 Karami S, Brennan P, Navratilova M, Mates D, Zaridze D, Janout V, Kollarova H, Bencko V, Matveev V, Szesznia-Dabrowska N, Holcatova I, Yeager M, Chanock S, Rothman N, Boffetta P, Chow WH and Moore LE: Vitamin D pathway genes, diet, and risk of renal cell carcinoma. Int J Endocrinol 2010: 879362, 2010.

68 Muller DC, Fanidi A, Midttun O, Steffen A, Dossus L, BoutronRuault MC, Severi G, Kühn T, Katzke V, de la Torre RA, González CA, Sánchez MJ, Dorronsoro M, Santiuste C, Barricarte A, Khaw KT, Wareham N, Travis RC, Trichopoulou A, Giotaki M, Trichopoulos D, Palli D, Krogh V, Tumino R, Vineis P, Panico S, Tjønneland A, Olsen A, Bueno-de-Mesquita HB, Peeters PH, Ljungberg B, Wennberg M, Weiderpass E, Murphy N, Riboli E, Ueland PM, Boeing H, Brennan P and Johansson M: Circulating 25hydroxyvitamin D3 in relation to renal cell carcinoma incidence and survival in the EPIC cohort. Am J Epidemiol 180(8): 810-820, 2014. 
69 Pospiech E, Ligeza J, Wilk W, Golas A, Jaszczynski J, Stelmach A, Ryś J, Blecharczyk A, Wojas-Pelc A, Jura J and Branicki W: Variants of SCARB1 and VDR involved in complex genetic interactions may be implicated in the genetic susceptibility to clear cell renal cell carcinoma. Biomed Res Int 2015: 860405, 2015.

70 Ben Fradj MK, Kallel A, Gargouri MM, Chehida MA, Sallemi A, Ouanes Y, Rhouma SB, Riadh J, Feki M, Nouira Y, Kaabachi $\mathrm{N}$ : Association of FokI polymorphism of vitamin D receptor with urothelial bladder cancer in Tunisians: role of tobacco smoking and plasma vitamin D concentration. Tumour Biol 37(5): 6197-6203, 2016.

71 Zhao Y, Chen C, Pan W, Gao M, He W, Mao R, Lin T, Huang J: Comparative efficacy of vitamin $\mathrm{D}$ status in reducing the risk of bladder cancer: A systematic review and network meta-analysis. Nutrition 32(5): 515-523, 2016.

72 Mohan R, Mohan G, Scott JX, Rajendran A, Paramasivam V and Ravindran M: Vitamin D insufficiency among children with cancer in India. Indian J Med Paediatr Oncol 37(1): 14-19, 2016.

73 Revuelta Iniesta R, Rush R, Paciarotti I, Rhatigan EB, Brougham FH, McKenzie JM and Wilson DC: Systematic review and meta-analysis: Prevalence and possible causes of vitamin $\mathrm{D}$ deficiency and insufficiency in pediatric cancer patients. Clin Nutr 35(1): 95-108, 2016.

74 Rai V, Dietz NE, Dilisio MF, Radwan MM and Agrawal DK: Vitamin $D$ attenuates inflammation, fatty infiltration, and cartilage loss in the knee of hyperlipidemic microswine. Arthritis Res Ther 18(1): 203, 2016.

75 Ruza E, Sotillo E, Sierrasesumaga L, Azcona C and PatinoGarcia A: Analysis of polymorphisms of the vitamin D receptor, estrogen receptor, and collagen Ialphal genes and their relationship with height in children with bone cancer. J Pediatr Hematol Oncol 25(10): 780-786, 2003.

76 Tekgunduz SA, Yesil S, Oren AC, Tanyildiz HG, Candir MO, Bozkurt C and Şahin G: Vitamin D receptor (VDR) polymorphisms in pediatric patients presenting withHodgkin's lymphoma. J Pediatr Hematol Oncol 39(2): e59-e61, 2017.

77 Dawidowska M, Kosmalska M, Sedek L, Szczepankiewicz A, Twardoch M, Sonsala A, Szarzyńska-Zawadzka B, Derwich K, Lejman M, Pawelec K, Obitko-Płudowska A, PawińskaWąsikowska K, Kwiecińska K, Kołtan A, Dyla A, Grzeszczak W, Kowalczyk JR, Szczepański T, Ziętkiewicz E and Witt M: Association of germline genetic variants in $R F C, I L 15$ and $V D R$ genes with minimal residual disease in pediatric B-cell precursor ALL. Sci Rep 6: 29427, 2016.
78 Tantawy M, Amer M, Raafat T and Hamdy N: Vitamin D receptor gene polymorphism in Egyptian pediatric acute lymphoblastic leukaemia correlation with BMD. Meta Gene 9: 42-46, 2016.

79 Gascoyne DM, Lyne L, Spearman H, Buffa FM, Soilleux EJ and Banham AH1: Vitamin D receptor expression in plasmablastic lymphoma and myeloma cells confers susceptibility to vitamin D. Endocrinology 158(3): 503-515, 2017.

$80 \mathrm{He}$ Y, Ou C, Pang W, Lin Y, He J, Li C and Lin X: Genetic association of $V D R$ polymorphisms and multiple myeloma susceptibility: a case control study. Int J Clin Exp Pathol 10(3): 3538-3542, 2017.

81 Esfahani A and Ghoreishi Z: Is there any association between vitamin $\mathrm{D}$ receptor polymorphisms and acute myeloid leukaemia? Ann Oncol 27(suppl 6): 938P, 2016.

$82 \mathrm{Wu} \mathrm{X}$, Cheng $\mathrm{J}$ and Yang K: Vitamin D-related gene polymorphisms, plasma 25-hydroxy-vitamin $\mathrm{D}$, cigarette smoke and non-small cell lung cancer (NSCLC) Risk. Int J Mol Sci 17(10): E1597, 2016.

83 Choi JY, Yi JW, Lee JH, Song RY, Yu H, Kwon H, Chai YJ, Kim $\mathrm{SJ}$ and Lee KE: VDR mRNA overexpression is associated with worse prognostic factors in papillary thyroid carcinoma. Endocr Connect 6(3): 172-178, 2017.

84 Mackawy AM, Al-Ayed BM and Al-Rashidi BM: Vitamin D deficiency and its association with thyroid disease. Int J Health Sci (Qassim) 7(3): 267-275, 2013.

85 Vaughan-Shaw PG, O'Sullivan F, Farrington SM, Theodoratou E, Campbell H, Dunlop MG and Zgaga L: The impact of vitamin D pathway genetic variation and circulating 25hydroxyvitamin $\mathrm{D}$ on cancer outcome: systematic review and meta-analysis. Br J Cancer 116(8): 1092-1110, 2017.
Received May 29, 2017

Revised June 15, 2017

Accepted June 19, 2017 